\title{
Quality of Juniper Essential Oil (Oleum Juniperi) in the South Slovakia and it's Curative and Industrial Utilization
}

\author{
Ivan Salamon, Peter Petruska \\ Department of Ecology, Faculty of Humanities and Natural Sciences, University of Presov, Presov, SLOVAKIA.
}

\begin{abstract}
Common juniper, Juniperus communis L., is a shrub or tree species belonging to the Cypress family (Cupressaceae). It has wide ecological amplitude and the aromatic plants occur abundantly in dry sunny hillsides, as well as the subalpine level. The essential oil is distilled from the fresh and dry black, ripe berries. Juniper essential oil (Oleum juniper) is transparent, fluid and colourless, sometimes with a tinge of greenishyellow. The principal essential oil constituent is pinene, which has two main isomers, $\alpha$ - and $\beta$-pinene; $\alpha$-pinene is the dominant. The principal properties of the oil are antiinflammatory, anti-microbial, anti-septic and diuretic. The recent research demonstrates that pinene is also helpful at mitigating the damages of hepatoma carcinoma and is viable as a potential anti-tumor drug. Juniper berries with a high pinene contents are an important and essential raw material in the distilled spirits industry. "Borovicka", as Slovak national alcoholic beverage, is a spirit made from the fruits. The results of essential oil qualitative-quantitative characteristics show great differences among juniper raw materials harvested in the Cerova Highlands - Chramec Area (the South Slovakia), where its biotopes are occurred on large areas (319.44 ha).
\end{abstract}

Key words: Berries, Cancer, Curative Effects, Juniper, Pinene, Spirits.

\section{INTRODUCTION}

Common Juniper (Juniperus communis L.) is a slow-growing coniferous shrub belonging to the family Cupressaceous, found mainly in temperate and subtropical regions of the northern hemisphere. It is a wind-pollinated, dioecious species, with male and female flowers growing on separate plants. (Cooper et al) The female produces fleshy cones (galbulae; commonly referred to as berries, due to their fleshy texture), that are green in colour at first and take 2-3 years to mature, when they attain a distinctive purple colour (Ward, 2010). Germination requires passage through the gut of a bird, or if falling onto the ground, 1-2 years exposure to allow the cones to break down to expose the seed.

Due to its former extensive distribution juniper is associated with a rich folklore and diverse ethno botanical uses, including medicinal, veterinary and culinary uses. There is a long tradition in Slovak Republic of using aromatic oils - travelling "oilmen" prepared the essential oils and peddled them along with other pharmaceutical preparations between villages and towns. The essential oil (Oleum juniper) obtained by distillation or pressing various juniper parts were used as the basis of many treatments with the practice becoming widespread during from $16^{\text {th }}$ to $19^{\text {th }}$ centuries (Hroziencik, 1981).

The aims of the present study were to use isolated essential oil and GC-FID method to elucidate the levels and patterns of juniper chemo type diversity in the South Slovakia (the Cerova Highlands) to inform about the curative and industrial properties.

\section{MATERIAL AND METHODS}

The total area of juniper recorded throughout the Cerova Highlands was 463.58 ha.
DOI: $10.5530 /$ ijper.51.3s.70

Correspondence:

Peter Petruska,

Department of Ecology.

Univesity of Presov. 08001

Presov. SLOVAKIA

Contact: 00421949413675

E-Mail: petruskaml@gmail.

com 
4 sites identified in the Chramec Area (319.44 ha) of 2 from the Wolf Valley (an abandonment of grazing regimes) and 2 from the Warm Valley (an inappropriate management by over-grazing), were surveyed for juniper formations between May to October during 2016. The extent of juniper scrubs at each site was established by walking around the perimeter of all extant shrubs and geo-referencing the enclosing boundary using a Garmin 60 GPS. Altitude (meters above sea level), slope (estimated by eye to the nearest $5^{\circ}$ ) and aspect were also recorded (Table 1).

A soil samples were collected for analysis in the laboratory, which is determined the sandy soil types. The selection of ripe galbulaes (cones) was collected from each site surveyed in order to examine their weight, for essential oil isolation and determination of main components.

Each sample of juniper fruits with weight of $25 \mathrm{~g}$ was grounded in a blender. The essential oil from this rawmaterial was prepared by hydro-distillation ( 2 hours) in Clevenger-type apparatus according to the European Pharmacopoeia and a mixture of hexane was used as a collecting solvent. The essential oils stored under $\mathrm{N}_{2}$ at $+4{ }^{\circ} \mathrm{C}$ in the dark space before their composition identification.

The GC-FID analysis of the juniper essential oils was carried out using a Vega Series Carloerba Gas Chromatograph, connected to a Spectrophysics SP 4270 integrator. The following operating conditions were used: column: DB5, $30 \mathrm{~m}$ x $0.32 \mathrm{~mm}$ i.d., film thickness: $0.25 \mathrm{~mm}$, carrier gas: Nitrogen, adjusted to a flux of $1 \mathrm{ml} / \mathrm{min}$, injection and FID-detector temperatures: $220{ }^{\circ} \mathrm{C}$ respectively $250^{\circ} \mathrm{C}$. Components were identified by their GC retention times, and the resulting values were comparable to those of literature. Oil component standards for comparison were supplied by Extrasynthese Ltd. and Sigma-Aldrich.

Results are presented in the percentage. Percentage of single chromatographic peak areas was measured on the basis of area of the single peaks to the total peak area ratio. Statistical analysis were done by using confidence intervals $(n=6)$ on the significant level $\mathrm{p}<0.05$ with calculation through the mean, standard deviation and standard error.

\section{RESULTS \& DISCUSSION}

Today, juniper population is found in a wide range of open habitats, at varying altitudes and growing in a wide range of soil types (Cooper et al) It favors free-draining soils, rocky outcrops and rarely inhabits wet conditions (Thomas et al, 2007). The species has a low tolerance to shade (Grubb et al, 1996) and is gradually excluded from woodland. The evidence of this claim is weights of 100 ripe galbulaes, which are presented in Table 2. The markedly smallest and lightest fruits (10.99 $\mathrm{g} \pm 0.10)$ were collected at the locality No. 1, when juniper plants are growing with another woody species. These are creating partially a shadow-casting and competitive position.

Light yellow or colorless pure essential oils were obtained from $25 \mathrm{~g}$ of dry fruit samples. Yield ranged from 0.9 to $1.8 \%$ (v/w) on a dry weight basis (Table 3). Reaffirm is presented the lowest quantity of essential oil on a dry weight basis of juniper berries $(0.90 \% \pm 0.15)$ at the locality No. 1. Juniper berries usually contain $0.2-3.4 \%$, usually $1.0-2.0 \%$, volatile oil, depending on geography, altitude, ripeness and other factors, including stress factors on site of plant population growth (Small, 1997).

The essential oil of juniper is made up mostly of monoterpenes (ca. $58 \%$ ), mainly $\alpha$ - pinene, $\beta$ - myrcene, and sabinene (Duke et al). The chemistry of juniper berry oil (chemo types) was reviewed by Lawrence long since in 1987. Main chemical composition of essential oils of different plant origin from the South Slovakia is presented in Table 4. Most of the investigated juniper raw-material was characterized by monoterpene hydrocarbons fraction in the essential oils. Content of a monoterpene, $\alpha$-pinene, varied drastically according to the harvesting sites (Table 4). It was found to be as a principal constituent with the highest content on $48.00 \pm$ 4.10 in the juniper berry oil at the site No. 4. Quantities of another components (excepting myrcene, as an olefinic natural organic monoterpene) were not differentiated in regard to the site origin.

$\alpha$-Pinene is an organic compound of the terpene class, one of two isomers of pinene. The Kusuhara and his team (2012) study on mice showed, for the first time, that pinene could slow the growth of tumors but could not identify the mechanism through which it worked. A 2013 study looking at its effects on neuroblastoma cells found that pinene decreased proliferation of cancerous cells (Elanur et al). Finally, results were showed that pinene was also helpful at mitigating the damages of hepatoma carcinoma and was viable as a potential antitumor drug (Chen et al).

In the production of "Borovička" - the Slovak alcoholic beverage the components are: alcohol, juniper berries and water. Producers of the popular alcoholic beverage shall be kept to the original recipe coming from the second half of the 18th century. According to the recent Slovak legislation "Borovička" must have a minimum alcohol content of $37.5 \%$ and more (up to $60 \%$ ) with the aroma, which is similar to that of pine, but more peppery, hot and balsamic, with a burning, somewhat 


\begin{tabular}{|c|c|c|c|c|c|c|}
\hline Site & $\begin{array}{l}\text { Geographical } \\
\text { latitude }\end{array}$ & Terrestrial longitude & $\begin{array}{c}\text { Altitude } \\
{[\mathrm{m}]}\end{array}$ & Aspect & Slope & $\begin{array}{l}\text { Area } \\
\text { [ ha ] }\end{array}$ \\
\hline No. 1 & N 48015,209' & E 020 $10,308^{\prime}$ & 274 & south & $35^{\circ}$ & 0.50 \\
\hline No. 2 & N 48015,342' & E 020 $10,603^{\prime}$ & 248 & south-east & $40^{\circ}$ & 1.50 \\
\hline No. 3 & N 48016,240' & E 020 $10,539^{\prime}$ & 200 & east & $25^{\circ}$ & 1.00 \\
\hline No. 4 & N 48 $16,183^{\prime}$ & E 020 $10,453^{\prime}$ & 196 & north-west & $30^{\circ}$ & 3.00 \\
\hline
\end{tabular}

\begin{tabular}{|c|c|c|c|c|c|}
\hline Site & $\bar{x}[\mathbf{g}]$ & $\sigma$ & se & $\begin{array}{c}\bar{x} \pm t \times s e \\
{[\mathrm{~g}]}\end{array}$ & Total weight of sample [g] \\
\hline No. 1 & 10.99 & 0.09 & 0.040 & $10.99 \pm 0.10$ & 153.48 \\
\hline No. 2 & 15.08 & 0.19 & 0.085 & $15.08 \pm 0.22$ & 371.55 \\
\hline No. 3 & 14.04 & 0.15 & 0.067 & $14.04 \pm 0.17$ & 425.98 \\
\hline No. 4 & 14.64 & 0.14 & 0.060 & $14.64 \pm 0.15$ & 543.90 \\
\hline
\end{tabular}

Legend: $\bar{x}$ mean, $\sigma$ : standard deviation, se: standard error, $\bar{x}+t \times$ se : confidence intervals on the significant level $p<0.05$

\begin{tabular}{|c|c|c|}
\hline \multicolumn{2}{|c|}{$\begin{array}{c}\text { Table 3: Juniper fruit yield of essential oil of in } \% \\
\text { (v/w, expressed on a dry weight) }\end{array}$} \\
\hline Site & Sample & Essential oil yield (\%) \\
\hline \multirow{2}{*}{ Wolf Valley } & No. 1 & $0.90 \pm 0.15$ \\
\cline { 2 - 3 } & No. 2 & $1.80 \pm 0.20$ \\
\hline \multirow{2}{*}{ Warm Valley } & No. 3 & $1.60 \pm 0.15$ \\
\cline { 2 - 3 } & No. 4 & $1.40 \pm 0.25$ \\
\hline
\end{tabular}

\begin{tabular}{|c|c|c|c|c|c|}
\hline \multirow{2}{*}{$\begin{array}{c}\text { Main } \\
\text { compounds }\end{array}$} & \multirow{2}{*}{$\begin{array}{l}\text { GC-FID } \\
\text { tR (min) }\end{array}$} & \multicolumn{2}{|c|}{ Wolf Valley } & \multicolumn{2}{|c|}{ Warm Valley } \\
\hline & & No. 1 & No. 2 & No. 3 & No. 4 \\
\hline a-pinene & 8.28 & $37.75 \pm 2.39$ & $37.50 \pm 2,07$ & $45.00 \pm 2.60$ & $48.00 \pm 4.10$ \\
\hline$\beta$-pinene & 13.31 & $2.57 \pm 0.92$ & $2.55 \pm 0.92$ & $2.51 \pm 0.92$ & $2.50 \pm 0.92$ \\
\hline sabinene & 14.35 & $19.52 \pm 2.07$ & $20.03 \pm 1.27$ & $16.78 \pm 1.27$ & $22.56 \pm 2.90$ \\
\hline$\beta$-phellandrene & 16.11 & $0.08 \pm 0.01$ & $0.08 \pm 0.02$ & $0.07 \pm 0.02$ & $0.08 \pm 0.03$ \\
\hline camphene & 16,53 & $0.17 \pm 0.03$ & $0.35 \pm 0.05$ & $0.16 \pm 0.02$ & $0.32 \pm 0.06$ \\
\hline myrcene & 17.16 & $13.54 \pm 1.92$ & $7.58 \pm 2,12$ & $9.52 \pm 1.92$ & $6.55 \pm 3.02$ \\
\hline limonene & 19.21 & $3.03 \pm 1.34$ & $1.50 \pm 0.92$ & $4.53 \pm 0,92$ & $5.50 \pm 0.92$ \\
\hline Y-terpinene & 19.60 & $0.30 \pm 0.08$ & $0.37 \pm 0.11$ & $0.26 \pm 0.05$ & $0.36 \pm 0.06$ \\
\hline terpinolene & 23.69 & $0.40 \pm 0.19$ & $0.40 \pm 0.18$ & $0.35 \pm 0.07$ & $0.38 \pm 0.08$ \\
\hline 1-terpinene-4-ol & 24.40 & $1.25 \pm 0,85$ & $1.56 \pm 0,92$ & $0.95 \pm 0,09$ & $0.91 \pm 0,09$ \\
\hline$\beta$-elemene & 35.13 & $0.30 \pm 0.01$ & $0.43 \pm 0.02$ & $0.23 \pm 0.01$ & $0.38 \pm 0.01$ \\
\hline boranylacetate & 38.67 & $0.25 \pm 0.05$ & $0.40 \pm 0.09$ & $0.48 \pm 0.09$ & $0.43 \pm 0.09$ \\
\hline Y-elemene & 40.62 & $1.74 \pm 0.47$ & $1.16 \pm 0.26$ & $1.51 \pm 0.11$ & $1.00 \pm 0.06$ \\
\hline (Z)- $\beta$-farnesene & 43.33 & $1.52 \pm 0.29$ & $1.51 \pm 0.49$ & $1.35 \pm 0.64$ & $1.44 \pm 0.29$ \\
\hline a-caryophyllene & 45.19 & $4.51 \pm 1.40$ & $8.51 \pm 2.62$ & $3.51 \pm 1.95$ & $6.31 \pm 1.38$ \\
\hline germacrene D & 45.98 & $2.05 \pm 0.96$ & $1.58 \pm 0.81$ & $1.81 \pm 0.95$ & $1.22 \pm 0.97$ \\
\hline a-gurjunene & 47.59 & $1.04 \pm 0.14$ & $0.42 \pm 0.09$ & $1.08 \pm 0.05$ & $0.25 \pm 0.05$ \\
\hline Y-cadinene & 49.41 & $0.19 \pm 0.06$ & $0.27 \pm 0.07$ & $0.10 \pm 0.03$ & $0.22 \pm 0.07$ \\
\hline$\beta$-cadinene & 50.22 & $2.40 \pm 1.03$ & $3.60 \pm 1.10$ & $2.05 \pm 0.78$ & $3.53 \pm 1.76$ \\
\hline$\delta$-cadinene & 53.02 & $0.21 \pm 0.08$ & $1.84 \pm 0.84$ & $0.16 \pm 0.04$ & $1.54 \pm 0.73$ \\
\hline
\end{tabular}


bitter taste. This odor is dependent on the composition of juniper essential oil, which is rich in pinene constituents.

\section{CONCLUSION}

The obtained results suggest that the content and composition of essential oil of juniper berries (Juniperus communis L.) varies depending on the age of plant individuals and sites of population occurrence. The high $\alpha$-pinene content of juniper essential has a perspective as a potential anti-tumor natural product. To know chemical composition of the juniper raw material is very important for industrial production of the "Borovička" - alcoholic beverage. In regard to the quality of Slovak national liquor, distiller companies need to prefer heaviness juniper fruits with the highest pinene content, as donors of aroma and odor.

\section{ACKNOWLEDGEMENTS}

This research was supported by the Slovak Research and Development Agency (SRDA), the project: APVV-140843: "Research of possibilities of growing juniper (Juniperus communis L.) for the production of fruits".

\section{CONFLICT OF INTEREST}

None

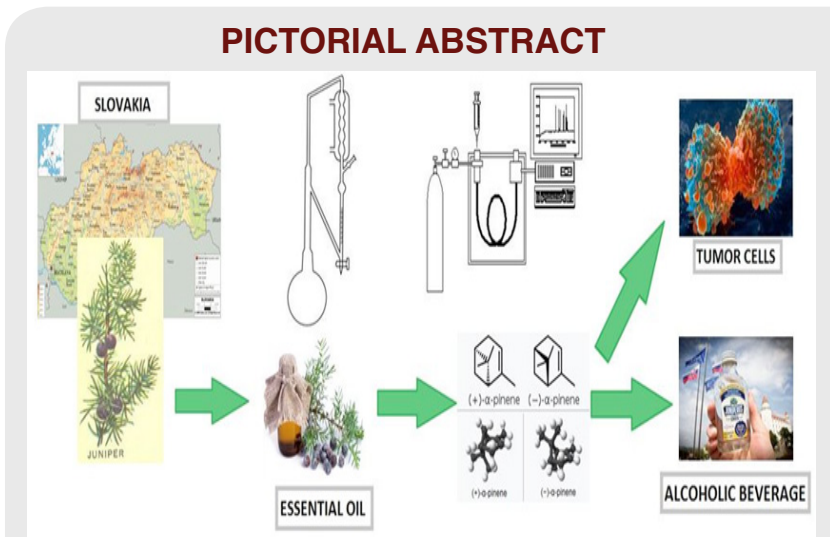

\section{ABOUT AUTHORS}

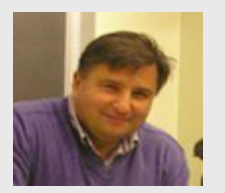

Assoc. Prof. Ivan Salamon: An university teacher and scientist, is the managing investigator of several R \& D projects of medicinal and aromatic plants. He is the principal author of the patent - the freeze-drying technology (lyophilization), as unique methods of anthocyanin isolation from medicinal plant small fruits, Chamomile variety "LIANKA" with the high content of $/-/-\alpha-$ bisabolol and Peppermint variety "KRISTINKA" with the high content of menthol of essential oils.

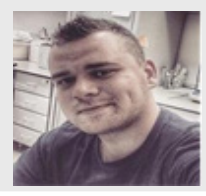

Bc. Peter Petruska: is an young scientist. His research work deals with the aspects of growth, production, qualitative-quantitative characteristics of essential oils and their antioxidative effects.

Cite this article: Salamon I, Petruska P. Quality of Juniper Essential Oil (Oleum Juniperi) In the South Slovakia and it's Curative and Industrial Utilization. Indian J of Pharmaceutical Education and Research. 2017;51(3)Suppl:S479-82. 